\title{
Herbivory in the Northern Curly-tailed Lizard (Leiocephalus carinatus)
}

\section{Bonnie K. Kircher*, Christopher D. Robinson, and Michele A. Johnson}

Trinity University, Department of Biology, San Antonio, Texas 78212, USA.

*Corresponding author (kircherbk@gmail.com)

Date of publication: 19 May 2014.

Citation: Kircher BK, Robinson CD, \& Johnson MA. (2014) Herbivory in the Northern Curly-tailed Lizard (Leiocephalus carinatus). Caribbean Herpetology 50:1-2.

Leiocephalus carinatus (Northern curly-tailed lizard) is distributed throughout the Cayman Islands, Cuba, and the Bahamas, and has been introduced in southern Florida (Schwartz \& Henderson 1991). Most species of Leiocephalus, and L. carinatus in particular, have an opportunistic diet (Henderson \& Powell 2009). One important component of the curly-tailed lizard diet is arthropods-primarily ants, beetles, cockroaches, and lepidopterans (Schoener et al. 1982; reviewed in Henderson \& Powell 2009). Curly-tailed lizards are also known predators of smaller lizards, particularly anoles (e.g., Schoener et al. 2002). In addition, their diet is comprised of up to $47 \%$ plant matter, most commonly fruits and flowers (Schoener et al. 1982), and Grant (1940) reported one observation of L. carinatus consuming flowers of the Beach Morning Glory (Ipomoea pescaprae) in the Cayman Islands. Despite the unusually high concentration of plant matter in the diet of these lizards, documented observations of herbivory in this group remain relatively rare.

On 21-23 July 2013 we observed two separate events of herbivory in L. carinatus, in which individual adults were eating flowers from the Beach Morning Glory (Ipomoea pescaprae) on a private beach on Crooked Island, Bahamas (22.773 N, -74.205 W). Each lizard picked off parts of the flower petals and masticated and swallowed them, feeding for about five minutes each. On 23 July 2013, a third adult L. carinatus was observed in the same location with a wilted morning glory flower in its mouth (Fig. 1).

Herbivory in lizards most commonly evolves in species that occur on small islands, and is thought to result from a lower abundance of available arthropod prey in those habitats (Schoener et al. 1982; Cooper \& Vitt 2002; Dutra et al. 2011). Further, Schoener et al. (1982) and Cooper \& Vitt (2002) found that larger lizards are more likely to consume plant matter than smaller lizards, perhaps because of the greater caloric needs associated with larger body size. Our observation of flower consumption by large L. carinatus on the small $\left(148 \mathrm{~km}^{2}\right)$ Crooked Island is consistent with both of these previously described patterns.

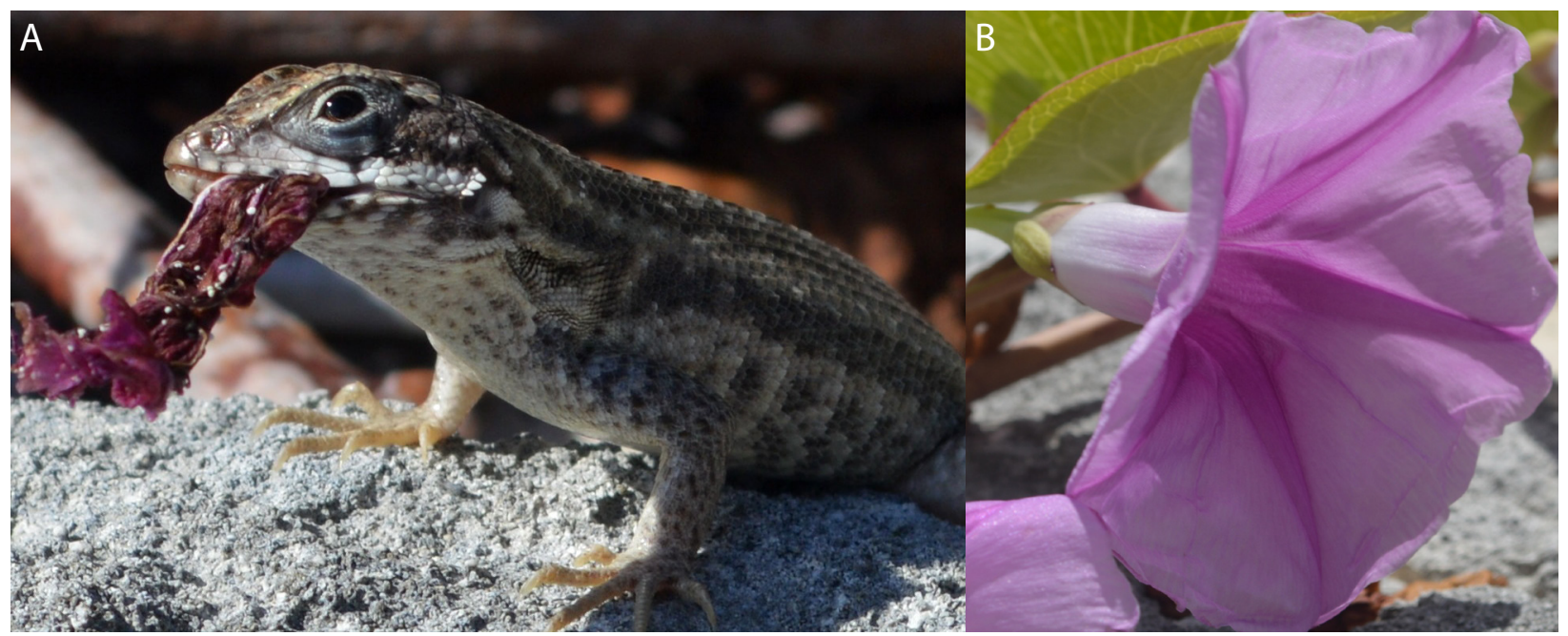

Figure 1. Leiocephalus carinatus (A) feeding on flowers (B) of the Beach Morning Glory (Ipomoea pescaprae). 


\section{References}

Cooper WE, \& Vitt LJ. (2002) Distribution, extent, and evolution of plant consumption by lizards. Journal of Zoology, 257, 487-517.

Dutra GF, Siqueira CC, Vrcibradic D, Kiefer MC, \& Rocha CFD. (2011) Plant consumption of insular and mainland populations of a tropical lizard. Herpetologica, 67, 32-45.

Grant, C. (1940) The herpetology of the Cayman Islands. Bulletin of the Institute of Jamaica, 2, 1-65.

Henderson RW, \& Powell R. (2009) Leicophalus carinatus Gray, 1827, pp. 138-140. In: Natural History of West Indian Amphibians and Reptiles. University Press of Florida, Gainesville.

Schoener TW, Slade JB, \& Stinson CH. (1982) Diet and sexual dimorphism in the very catholic lizard genus, Leiocephalus of the Bahamas. Oecologia, 53, 160-169.

Schoener TW, Spiller DA, \& Losos JB. (2002) Predation on a common Anolis lizard: can the food-web effects of a devastating predator be reversed? Ecological Monographs, 72, 383-407.

Schwartz A, \& Henderson RW. (1991) Amphibians and Reptiles of the West Indies: Description, Distributions, and Natural History. University of Florida Press, Gainesville, $423 \mathrm{pp}$. 